\title{
Characterization Study of Electric Arc Furnace Dust Phases
}

\author{
Janaína Gonçalves Maria da Silva Machado*, Feliciane Andrade Brehm, \\ Carlos Alberto Mendes Moraes ${ }^{\mathrm{b}}$, Carlos Alberto dos Santos ${ }^{\mathrm{c}}$, Antônio Cezar Faria Vilela \\ arron and Steelmaking Research Group/LASID, \\ Federal University of Rio Grande do Sul - FRGS, Technology Center, \\ Av. Bento Gonçalves, 9500, PO Box 15021, 91501-970 Porto Alegre - RS \\ ${ }^{\mathrm{b}}$ Materials Characterization Group/NucMat, University of Vale do Rio dos Sinos - UNISINOS, \\ São Leopoldo - RS \\ 'Institute of Physics, UFRGS, Campus do Vale, Porto Alegre - RS
}

Received: December 2, 2004; Revised: July 13, 2005

\begin{abstract}
Electric arc furnace dust (EAFD) is a solid waste generated in the collection of particulate material during steelmaking process in electric arc furnace. The aim of this work is to carry out a chemical and structural characterization of two EAFD samples with different Zn contents. Optical emission spectroscopy via inductively coupled plasma (ICP), X ray diffractometry (XRD) and Mössbauer spectroscopy analysis were carried out in such EAFD samples. From XRD measurements, the samples exhibits the following phases: $\mathrm{ZnFe}_{2} \mathrm{O}_{4}, \mathrm{Fe}_{3} \mathrm{O}_{4}$, $\mathrm{MgFe}_{2} \mathrm{O}_{4}, \mathrm{FeCr}_{2} \mathrm{O}_{4}, \mathrm{Ca}_{0.15} \mathrm{Fe}_{2.85} \mathrm{O}_{4}, \mathrm{MgO}, \mathrm{Mn}_{3} \mathrm{O}_{4}, \mathrm{SiO}_{2}$ and $\mathrm{ZnO}$. The phases detected by Mössbauer spectroscopy were: $\mathrm{ZnFe}_{2} \mathrm{O}_{4}, \mathrm{Fe}_{3} \mathrm{O}_{4}, \mathrm{Ca}_{0.15} \mathrm{Fe}_{2.85} \mathrm{O}_{4}$ and $\mathrm{FeCr}_{2} \mathrm{O}_{4}$. Magnesium ferrite $\left(\mathrm{MgFe}_{2} \mathrm{O}_{4}\right)$, observed in the XRD patterns as overlapped peaks, was not identified in the Mössbauer spectroscopy analysis.
\end{abstract}

Keywords: $E A F D$, characterization, XRD, Mössbauer spectroscopy

\section{Introduction}

Electric arc furnace dust (EAFD) is a solid waste generated during the steelmaking process. It is classified according to NBR $10004^{1}$ as dangerous solid waste-class I, because $\mathrm{Pb}$ and $\mathrm{Cd}$ elements leach in water exceeding the maximum limits permitted by the NBR $10005^{2}$. The State Foundation for Environmental Protection of Rio Grande do Sul - FEPAM - requires that this waste must be stored in an appropriate place, protected from rain. Due to the great generated amount, from 12 to $14 \mathrm{Kg}$ of dust per ton of steel, a study of the steel recycling alternatives is necessary.

In general, and especially in developed countries, the EAFD treatment processes mainly aim the zinc recovering. This is due to the fact that in the last 40 years this element has been used progressively in the galvanizing process of the carbon steel. When these steel scraps are reused, the contained zinc is evaporated during the melting (B. P. $907^{\circ} \mathrm{C}$ ), passing nearly all to EAFD, remaining very low amount in the steel and in the slag ${ }^{3}$.

In Brazil, the amount of galvanizing steel recycling is still small to use the major EAFD treatment technologies commercialized all over the world. Besides, there is the zinc ore extraction in Brazil. However, new researches have already been developed in order to recycle the EAFD expecting the increase of zinc in this waste.

As chemical and structural characterization of solid waste is a very important stage to evaluate recycling feasibility, several analytical techniques have been used to study EAFD. Comparing the elementary chemical analysis results, XRD and Mössbauer spectroscopy, it is possible to determine and to quantify the phases present in the EAFD samples studied.

This paper is concerned with chemical and structural characterization of two types of EAFD with different $\mathrm{Zn}$ contents.

\section{Materials and Methods}

Two EAFD samples with different $\mathrm{Zn}$ contents were collected from the dust removal system of a steel plant in southern Brazil. This company is characterized by special steel production with a varied chemical composition.

\subsection{Chemical characterization}

EAFD samples digestion - Brehm ${ }^{4}$ suggested that to get the EAFD complete digestion, the methodology must be done in two stages:

- $1^{\text {st }}$ stage: digestion via electric plate; and

- $2^{\text {nd }}$ stage: alkaline fusion of the insoluble waste from the $1^{\text {st }}$ stage.

To accelerate this procedure, the digestion via microwave oven was used, instead of electric plate (performance time $\approx 3$ hours). With microwave, the stage performance time is about 45 minutes and the results are the same. A flow diagram of the used methodology is displayed in Figure 1.

Sample 1 was used as a reference to determine the largest possible number of elements in the EAFD, according to the ones involved in the steelmaking in the EAF.

The techniques used for elementary chemical analysis of sample 1 are shown in Table 1.

In sample 2 the major elements ( $\mathrm{Fe}$ and $\mathrm{Zn}$ ) were analyzed: these ones are more interesting for the reduction study using carbon reducing agents to get ferrous concentrated ${ }^{5}$. The $\mathrm{Ca}, \mathrm{Cr}, \mathrm{Mg}$ elements were analyzed because they had been identified in the analytical results of structural characterization forming phases like $\mathrm{FeOCr}_{2} \mathrm{O}_{3}, \mathrm{CaFe}_{2} \mathrm{O}_{4}{ }^{6}$ and $\mathrm{MgFe}_{2} \mathrm{O}_{4}{ }^{7}$. The analytical results were obtained via ICP.

The silicon amount was not considered in both samples because most of this element evaporates during the $1^{\text {st }}$ stage of the digestion 
method used in the preparation of the samples for chemical analysis via ICP. As a result of that its amount in the dust would be lower. At the same time, its amount was not analyzed via other analytical method because it is known that most of this element appears as $\mathrm{SiO}_{2}$.

\section{2. $X$ ray diffraction}

The structural characterization of EAFD was performed through $\mathrm{X}$ ray diffraction analysis in a Siemens appliance model D500, in the Physics Institute of the Federal University of Rio Grande do $\mathrm{Sul}$ (UFRGS). X ray patterns of samples powdered to 400 mesh were obtained with monochromated $\mathrm{Cu} \mathrm{K \alpha}$ radiation in the $2 \theta$-range from $2^{\circ}$ to $140^{\circ}$ with a scan step of $0.05^{\circ} 2 \theta$, and fixed counting time of 1 second for each step. The patterns were analyzed by using the Philips X-Pert Software.

\subsection{Mössbauer spectroscopy}

Absorbers for Mössbauer spectroscopy measurements were prepared with appropriate amounts of ground (400 mesh) material to satisfy the ideal absorber thickness approximation ${ }^{8}$. The spectra were taken at room temperature using a constant acceleration electromechanical drive system with a multichannel analyzer for collecting and storing the data. The velocity scale was calibrated using a high-purity $6 \mu \mathrm{m}$ thick Fe foil. The hyperfine parameters were obtained by a leastsquares procedure assuming Lorentzian line shapes constrained to equal halfwidths. ${ }^{57} \mathrm{Co}$ in rhodium was used at room temperature as a source, with nominal activity of $10 \mathrm{mCi}$. Typical errors are $\pm 3 \%$ on hyperfine parameters and $\pm 5 \%$ on site occupancies.

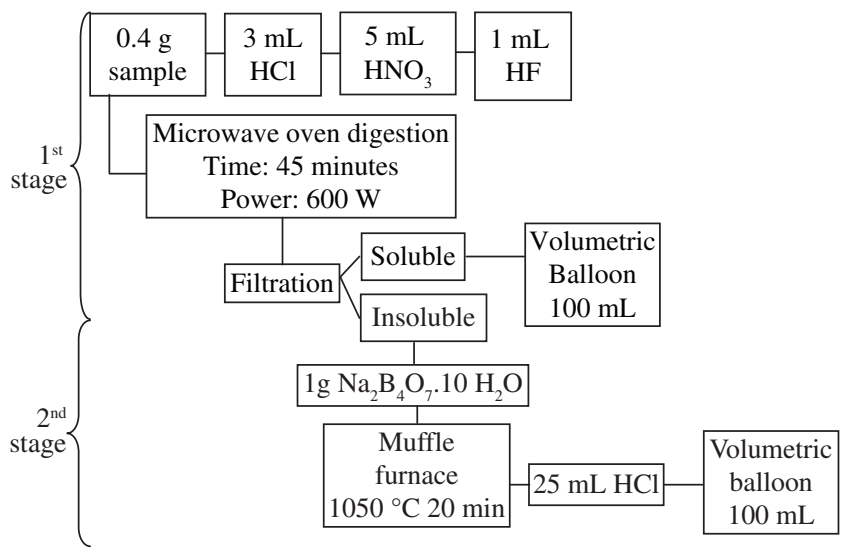

Figure 1. Methodology used for the EAFD samples digestion.

Table 1. Techniques used in the sample 1 elementary chemical analysis.

\begin{tabular}{ll}
\hline \multicolumn{1}{c}{ Elements } & \multicolumn{1}{c}{ Techniques } \\
\hline $\mathrm{Al}, \mathrm{Cd}, \mathrm{Pb}, \mathrm{Co}, \mathrm{Cu}$, & Atomic Absorption Spectrometry \\
$\mathrm{Cr}, \mathrm{Sn}, \mathrm{Mg}, \mathrm{Mn}, \mathrm{Mo}$, & \\
$\mathrm{Ni}, \mathrm{K}, \mathrm{Na}, \mathrm{Zn}$. & \\
\hline $\mathrm{Ca}$ & Inductively Coupled Plasma - Atomic \\
& Emission Spectroscopy (ICP-AES). \\
\hline $\mathrm{C}, \mathrm{S}$ & Combustion \\
\hline $\mathrm{Fe}$ & Volumetry \\
\hline
\end{tabular}

\section{Results and Discussions}

\subsection{Elementary chemical analysis}

The elementary results for samples 1 and 2 are presented in Tables 2 and 3. The Fe element in sample $1(42 \%)$ is smaller than in sample 2 (48.96\%). The contrary is observed for $\mathrm{Zn}$ : in sample 1, 12\% and in sample 2, 9.24\%. According to the literature ${ }^{9}$, about EAFD for carbon steel, the zinc contents are between $11.2 \%$ and $26.9 \%$. For the EAFD from stainless steel the contents are between $1.77 \%$ and $6.22 \%$. Therefore, Fe and $\mathrm{Zn}$ contents found in these EAFD samples are in the intermediate range.

The other elements (for example, $\mathrm{Ca}, \mathrm{Mg}, \mathrm{Cd}, \mathrm{Pb}, \mathrm{Cr}, \mathrm{Mn}$, and $\mathrm{Si}$ ) plus $\mathrm{O}$ complete the composition. It was decided to use elementary chemical composition because it has been determined in previous works ${ }^{4-6}$ that the EAF dust does not be constituted by the most stable binary metallic oxides, as it is usually showed by the majority of articles found in the literature ${ }^{10,11}$.

\section{2. $X$ ray diffraction}

The X ray diffraction patterns are displayed in Figures 2 and 3, and the obtained oxide phases are summarized in Table 4.

As it can be seen, $\mathrm{ZnFe}_{2} \mathrm{O}_{4}, \mathrm{Fe}_{3} \mathrm{O}_{4}, \mathrm{MgFe}_{2} \mathrm{O}_{4}, \mathrm{FeCr}_{2} \mathrm{O}_{4}, \mathrm{Mn}_{3} \mathrm{O}_{4}$, $\mathrm{MgO}, \mathrm{SiO}_{2}, \mathrm{Ca}_{0.15} \mathrm{Fe}_{2.85} \mathrm{O}_{4}$ and $\mathrm{ZnO}$ are present in both samples.

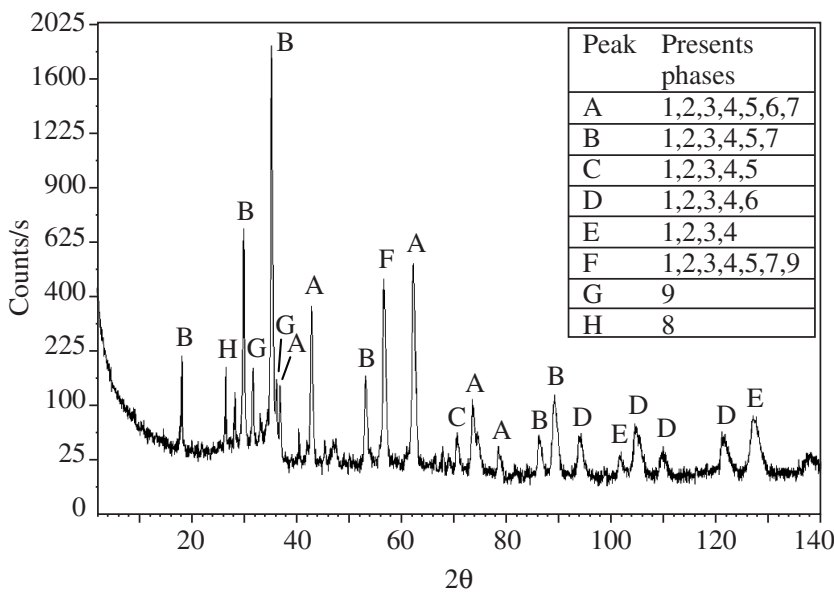

Figure 2. $\mathrm{X}$ ray diffraction (XRD) pattern of sample 1.

Table 3. Elementary results found in sample 2(wt. (\%)).

\begin{tabular}{lccccc}
\hline Element $(\%)$ & $\mathrm{Fe}$ & $\mathrm{Zn}$ & $\mathrm{Ca}$ & $\mathrm{Cr}$ & $\mathrm{Mg}$ \\
\hline Sample 2 & 48.96 & 9.24 & 3.28 & 2.90 & 1.65 \\
\hline
\end{tabular}

Table 2. Elementary results found in sample 1 (wt. (\%)).

\begin{tabular}{|c|c|c|c|c|c|c|c|c|c|c|c|c|c|c|c|c|c|c|}
\hline Element $(\%)$ & $\mathrm{Fe}$ & $\mathrm{Zn}$ & $\mathrm{Ca}$ & $\mathrm{Cr}$ & $\mathrm{Mg}$ & Co & $\mathrm{Cu}$ & $S$ & $\mathrm{Sn}$ & $\mathrm{Al}$ & $\mathrm{C}$ & $\mathrm{Pb}$ & $\mathrm{Mn}$ & Mo & $\mathrm{Ni}$ & $\mathrm{K}$ & $\mathrm{Na}$ & $\mathrm{Cd}$ \\
\hline Sample 1 & 42 & 12 & 4.87 & 3.20 & 2.21 & 0.004 & 0.36 & 0.292 & 0.25 & 0.36 & 1.61 & 1.26 & 1.65 & 0.09 & 0.17 & 1.32 & 1.6 & 0.03 \\
\hline
\end{tabular}




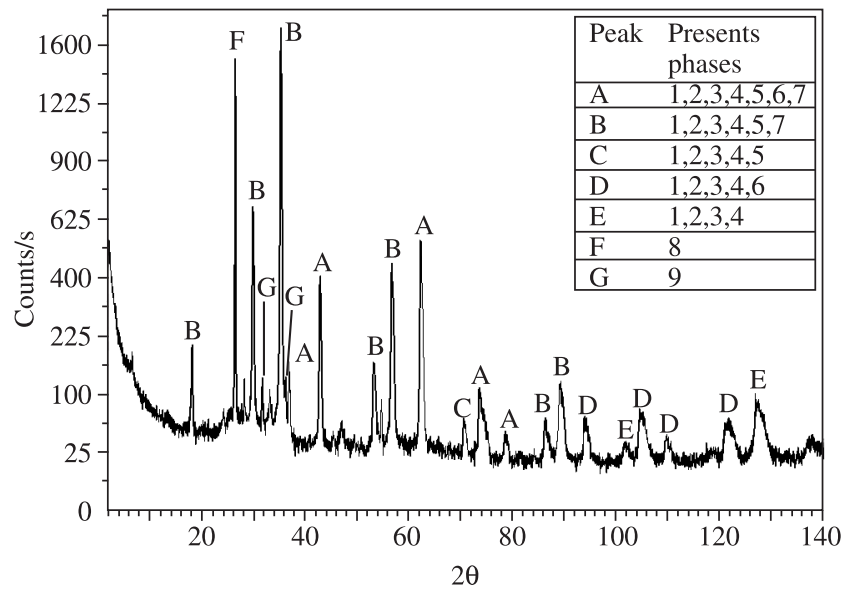

1. Franklinite - $\mathrm{ZnFe}_{2} \mathrm{O}_{4}(\mathrm{PDF}: 22-1012) ;$
2. Magnetite - $\mathrm{Fe}_{3} \mathrm{O}_{4}$ (PDF: $\left.11-0614\right) ;$
3. Magnesium-ferrite - $\mathrm{MgFe} \mathrm{O}_{4}$ (PDF: 17-0465);
4. Chromite - $\mathrm{FeCr}_{2} \mathrm{O}_{4}(\mathrm{PDF}: 34-0140) ;$
5. Calcium-magnetite - $\mathrm{Ca}{ }_{0.15} \mathrm{Fe}_{2.85} \mathrm{O}_{4}(\mathrm{PDF}: 46-0291)$;
6. Periclase - $\mathrm{MgO}(\mathrm{PDF}: 45-0946) ;$
7. Manganese oxide - $\mathrm{Mn} \mathrm{O}_{4}$ (PDF: 13-0162);
8. Quartz - $\mathrm{SiO}$ (PDF: $05-0490) ;$ and
9. Zincite - $\mathrm{ZnO}$ (PDF: $36-1451)$.

Figure 3. X ray diffraction (XRD) pattern of sample 2.

Table 4. Phases obtained in the XRD analysis of the studied EAFD samples.

\begin{tabular}{lcc}
\hline \multicolumn{1}{c}{ Phases } & Sample 1 & Sample 2 \\
\hline $\mathrm{ZnFe}_{2} \mathrm{O}_{4}$ & $\mathrm{X}$ & $\mathrm{X}$ \\
$\mathrm{Fe}_{3} \mathrm{O}_{4}$ & $\mathrm{X}$ & $\mathrm{X}$ \\
$\mathrm{MgFe}_{2} \mathrm{O}_{4}$ & $\mathrm{X}$ & $\mathrm{X}$ \\
$\mathrm{FeCr}_{2} \mathrm{O}_{4}$ & $\mathrm{X}$ & $\mathrm{X}$ \\
$\mathrm{Mn}_{3} \mathrm{O}_{4}$ & $\mathrm{X}$ & $\mathrm{X}$ \\
$\mathrm{MgO}$ & $\mathrm{X}$ & $\mathrm{X}$ \\
$\mathrm{ZnO}$ & $\mathrm{X}$ & $\mathrm{X}$ \\
$\mathrm{SiO}_{2}$ & $\mathrm{X}$ & $\mathrm{X}$ \\
$\mathrm{Ca}_{0.15} \mathrm{Fe}_{2.85} \mathrm{O}_{4}$ & $\mathrm{X}$ & $\mathrm{X}$ \\
\hline
\end{tabular}

However, except for $\mathrm{SiO}_{2}$ and $\mathrm{ZnO}$, the signals from all the phases exhibit overlapping in some extent, as shown in Figures 2 and 3. Because of such overlapping, also observed by $\mathrm{Heck}^{7}$, the presence of these phases cannot be unequivocally assured. As it will be shown, to improve the phases identification in EAFD samples it is necessary to use other techniques like, for example, Mössbauer Spectroscopy and Scanning Electron Microscopy with Energy Dispersive Spectroscopy and X ray Mapping Analysis. The Mössbauer Spectroscopy was used for investigation of these ferrous oxide phases $\mathrm{ZnFe}_{2} \mathrm{O}_{4}, \mathrm{Fe}_{3} \mathrm{O}_{4}$, $\mathrm{MgFe}_{2} \mathrm{O}_{4}, \mathrm{FeCr}_{2} \mathrm{O}_{4}, \mathrm{Ca}_{0.15} \mathrm{Fe}_{2.85} \mathrm{O}_{4}$.

\subsection{Mössbauer spectroscopy}

The Mössbauer spectrum for sample 2 is displayed in Figure 4. It is quite similar to that one obtained for sample 1 . The parameters obtained from fitting the spectra are presented in Table 5.

It is interesting to observe that the magnesium-ferrite phase $\left(\mathrm{MgFe}_{2} \mathrm{O}_{4}\right)$ identified in samples 1 and 2 through XRD, in overlapped peaks, was not observed in the Mössbauer spectra. Comparing

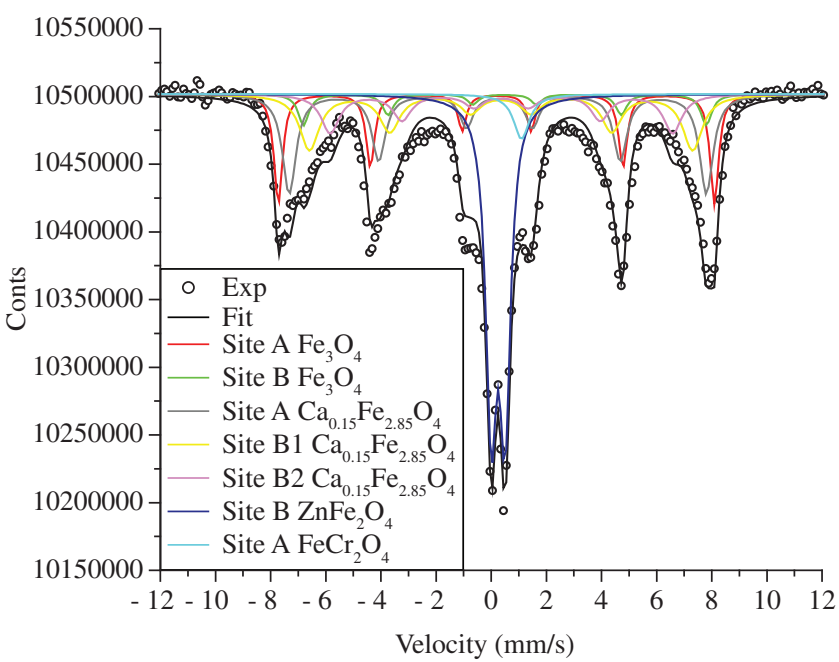

Figure 4. Mössbauer spectrum of sample 2.

Table 5. Mössbauer Parameters* used in the spectra fit of the EAFD samples at room temperature.

\begin{tabular}{cllcccc}
\hline Sample & & & $\begin{array}{c}\mathrm{H}_{\text {eff }} \\
(\mathrm{kOe})\end{array}$ & $\begin{array}{c}\delta / \mathrm{Fe} \\
(\mathrm{mm} / \mathrm{s})\end{array}$ & $\begin{array}{c}\Delta \mathrm{E}_{\mathrm{Q}} \\
(\mathrm{mm} / \mathrm{s})\end{array}$ & $\begin{array}{c}\Gamma \\
(\mathrm{mm} / \mathrm{s})\end{array}$ \\
\hline 1 & $\mathrm{Fe}_{3} \mathrm{O}_{4}$ & Site A & 489 & 0.29 & -0.01 & 0.37 \\
& & Site B & 453 & 0.55 & 0.01 & 0.61 \\
& $\mathrm{ZnFe}_{2} \mathrm{O}_{4}$ & Site A & - & 0.35 & 0.50 & 0.48 \\
& $\mathrm{FeCr}_{2} \mathrm{O}_{4}$ & Site A & - & - & 1.1 & 0.70 \\
& $\mathrm{Ca}_{0.15} \mathrm{Fe}_{2.85} \mathrm{O}_{4}$ & Site A & 470 & 0.38 & -0.06 & 0.59 \\
& & Site B & 418 & 0.53 & 0.01 & 0.70 \\
\hline 2 & $\mathrm{Fe}_{3} \mathrm{O}_{4}$ & Site A & 491 & 0.30 & -0.01 & 0.37 \\
& & Site B & 453 & 0.60 & 0.01 & 0.47 \\
& $\mathrm{ZnFe}_{2} \mathrm{O}_{4}$ & Site A & - & 0.35 & 0.50 & 0.47 \\
& $\mathrm{FeCr}_{2} \mathrm{O}_{4}$ & Site A & - & - & 1.1 & 0.70 \\
& $\mathrm{Ca}_{0.15} \mathrm{Fe}_{2.85} \mathrm{O}_{4}$ & Site A & 470 & 0.38 & -0.06 & 0.59 \\
& & Site B & 408 & 0.47 & 0.01 & 0.83 \\
\hline
\end{tabular}

$* \mathrm{H}_{\text {eff }}$, hyperfine field; $\delta / \mathrm{Fe}$, isomer shift relative to metallic iron; $\Delta \mathrm{E}_{\mathrm{Q}}$, quadrupole shift; and $\Gamma$, line width.

Mössbauer results with the $\mathrm{Mg}$ amount determined via ICP, it may be suggested that such phase is not present in the dust.

The Mössbauer parameters obtained for $\mathrm{Fe}_{3} \mathrm{O}_{4}, \mathrm{ZnFe}_{2} \mathrm{O}_{4}$ and $\mathrm{FeCr}_{2} \mathrm{O}_{4}$ in both samples are in agreement with those reported in the literature ${ }^{12-14}$.

The hyperfine field for the site assigned as $\mathrm{B}$ in $\mathrm{Ca}_{0.15} \mathrm{Fe}_{2.85} \mathrm{O}_{4}$ is an average between two fitted values, as illustrated in Figure 4. Such a behavior is due to the fact that calcium substitutes iron randomly at the site B, occupying in a disorganized form the iron place in the magnetite B site. The result is that, for each cell, there are different hyperfine interactions and, consequently, there is a hyperfine magnetic field distribution in this site ${ }^{15}$.

Values around $0.50 \mathrm{~mm} / \mathrm{s}$ for the line width are commonly found in the literature. Spectra with wide lines may indicate, among other things, sample disordering ${ }^{14}$.

Table 6 shows the ferrous quantification in the oxide phases found in the EAFD according to Mössbauer spectroscopy.

One of the most important characteristics of the Mössbauer Spectroscopy technique is its selectivity. If the emitter Mössbauer 
Table 6. Quantification of ferrous in the oxide phases present in the EAFD samples according to the Mössbauer spectroscopy.

\begin{tabular}{llcc}
\hline & Phase & Sample 1 $(\%)$ & Sample 2 (\%) \\
\hline $\mathrm{Fe}_{3} \mathrm{O}_{4}$ & Site A & 14.80 & 14.82 \\
& Site B & 7.71 & 5.33 \\
$\mathrm{ZnFe}_{2} \mathrm{O}_{4}$ & Site A & 27.01 & 27.05 \\
$\mathrm{FeCr}_{2} \mathrm{O}_{4}$ & Site A & 3.68 & 2.80 \\
$\mathrm{Ca}_{0.15} \mathrm{Fe}_{2.85} \mathrm{O}_{4}$ & Site A & 18.59 & 21.35 \\
& Site B1 & 16.26 & 17.39 \\
& Site B2 & 11.95 & 11.27 \\
\hline
\end{tabular}

isotope is, for example, ${ }^{57} \mathrm{Fe}$, the resonant absorption may only occur if there are identical nucleus inside the absorbent. In this way, even if the sample shows a great variety of compounds, only the ones which have a Mössbauer nucleus in their constitution, will be detected. Considering that the EAFD does not present only iron in its constitution, the results of the Mössbauer spectroscopy and the ICP analysis ( $\mathrm{Fe}$ and $\mathrm{Zn}$ content) were used to determine the amount of the main oxides phases $\left(\mathrm{Fe}_{3} \mathrm{O}_{4}, \mathrm{ZnFe}_{2} \mathrm{O}_{4}, \mathrm{FeCr}_{2} \mathrm{O}_{4}, \mathrm{Ca}_{0.15} \mathrm{Fe}_{2.85} \mathrm{O}_{4}\right.$ and $\mathrm{ZnO}$ ). Table 7 shows the analyzed samples composition according to these two techniques. The other oxide compounds with the elements $\mathrm{Si}, \mathrm{Cd}, \mathrm{Pb}, \mathrm{Mn}, \mathrm{Mg}$ complete the composition.

The amount of $\mathrm{ZnO}$ was determined as follows:

$1^{\text {st }}$ step: Determination $\mathrm{ZnFe}_{2} \mathrm{O}_{4}$ amount

$$
\begin{aligned}
& \% \mathrm{Fe}_{\mathrm{ZnFe}_{2} \mathrm{O}_{4}}=\frac{\% \mathrm{Fe}_{\text {total(via ICP) }} \mathrm{X} \mathrm{Fe}_{\mathrm{ZnFe}_{2} \mathrm{O}_{4} \text { (via Mössabaur) }}}{100} \\
& \% \mathrm{ZnFe}_{2} \mathrm{O}_{4}=\frac{\% \mathrm{Fe}_{\mathrm{ZnFe}_{2} \mathrm{O}_{4}} \mathrm{x} \overline{\mathrm{M}}_{\mathrm{Fe}_{\left(\mathrm{ZnF} \mathrm{O}_{4}\right)}}}{\mathrm{M}_{\mathrm{ZnFe}_{2} \mathrm{O}_{4}}} \\
& 2^{\text {st }} \text { step: Determination } \mathrm{ZnO} \text { amount } \\
& \% \mathrm{Zn}_{\mathrm{ZnF}_{2} \mathrm{O}_{4}}=\frac{\% \mathrm{ZnFe}_{2} \mathrm{O}_{4} \times \overline{\mathrm{M}}_{\mathrm{Zn}}}{\overline{\mathrm{M}}_{\mathrm{ZnFe}_{2} \mathrm{O}_{4}}} \\
& \frac{\% \mathrm{ZnO}}{\mathrm{ZnO}}=\% \mathrm{Zn}_{\text {total(via ICP) }}-\% \mathrm{Zn}_{\mathrm{ZnFe}_{2} \mathrm{O}_{4}} \\
& \overline{\mathrm{M}}_{\mathrm{Zn}}
\end{aligned}
$$

Where,

$\% \mathrm{Fe}_{\mathrm{ZnFe}_{2} \mathrm{O}_{4}}: \% \mathrm{Fe}$ in $\mathrm{ZnFe}_{2} \mathrm{O}_{4}$ phase;

$\% \mathrm{Fe}_{\text {total(via ICP) }}$ : wt. (\%) of total Fe determined via ICP;

$\% \mathrm{Fe}_{\mathrm{ZnFe}_{2} \mathrm{O}_{4} \text { (via Mössabauer) }}: \% \mathrm{Fe}$ in $\mathrm{ZnFe}_{2} \mathrm{O}_{4}$ phase determined via Mössbauer;

$\% \mathrm{ZnFe}_{2} \mathrm{O}_{4}: \% \mathrm{ZnFe}_{2} \mathrm{O}_{4}$ in samples;

$\overline{\mathrm{M}}_{\mathrm{Fe}(\mathrm{ZnFe} 2 \mathrm{O} 4}$ : molar weight of $\mathrm{Fe}$ in $\mathrm{ZnFe}_{2} \mathrm{O}_{4}$ phase;

$\overline{\mathrm{M}}_{\mathrm{ZnFe}_{2} \mathrm{O}_{4}}$ : molar weight of $\mathrm{ZnFe}_{2} \mathrm{O}_{4}$ phase;

$\% \mathrm{Zn}_{\mathrm{ZnFe}_{2} \mathrm{O}}: \% \mathrm{Zn}$ in $\mathrm{ZnFe}_{2} \mathrm{O}_{4}$ phase;

$\overline{\mathrm{M}}_{\mathrm{Zn}}$ : molar weight of $\mathrm{Zn}$;

$\% \mathrm{Zn}_{\mathrm{ZnO}}: \% \mathrm{Zn}$ in $\mathrm{ZnO}$ phase;

$\% \mathrm{Zn}_{\text {total(via ICP) }}$ : wt. (\%) of total $\mathrm{Zn}$ determined via ICP;

$\overline{\mathrm{M}}_{\mathrm{ZnO}}$ : molar weight of $\mathrm{ZnO}$ phase; and

$\% \mathrm{ZnO}: \% \mathrm{ZnO}$ in samples.

According to Table 7, it is observed that while the EAFD $\mathrm{Zn}$ content decreases, the $\mathrm{ZnO}$ phase content also decreases and the $\mathrm{ZnFe}_{2} \mathrm{O}_{4}$ content increases. The relation between the zinc content in these phases is shown in Table 8. The data from this table were calculated considering the amount of $\mathrm{Zn}$ in the $\mathrm{ZnFe}_{2} \mathrm{O}_{4}$ and $\mathrm{ZnO}$ phases in both EAFD studied samples.

The results shown in Table 7 and 8 are according to the literature, because for the EAFD with low $\mathrm{Zn}$ concentration, most of the $\mathrm{Zn}$
Table 7. Quantification of the mainly oxides phases in the studied EAFD samples.

\begin{tabular}{lcc}
\hline \multicolumn{1}{c}{ Phase } & Sample 1 $(\%)$ & Sample 2 $(\%)$ \\
\hline $\mathrm{Fe}_{3} \mathrm{O}_{4}$ & 13 & 14 \\
$\mathrm{ZnFe}_{2} \mathrm{O}_{4}$ & 24 & 29 \\
$\mathrm{FeCr}_{2} \mathrm{O}_{4}$ & 6 & 6 \\
$\mathrm{Ca}_{0.15} \mathrm{Fe}_{2.85} \mathrm{O}_{4}$ & 28 & 35 \\
$\mathrm{ZnO}$ & 7 & 2 \\
\hline
\end{tabular}

Table 8. Relation between $\mathrm{Zn}$ content in the $\mathrm{ZnFe}_{2} \mathrm{O}_{4}$ and $\mathrm{ZnO}$ phases for EAFD with different $\mathrm{Zn}$ contents.

\begin{tabular}{lcc}
\hline & $\begin{array}{c}\text { Sample } 1 \\
(12 \% \text { of } \mathrm{Zn})\end{array}$ & $\begin{array}{c}\text { Sample 2 } \\
(9.24 \% \text { of } \mathrm{Zn})\end{array}$ \\
\hline$\% \mathrm{Zn}$ in $\mathrm{ZnFe}_{2} \mathrm{O}_{4}$ & 55 & 84 \\
$\% \mathrm{Zn}$ in $\mathrm{ZnO}$ & 45 & 16 \\
\hline
\end{tabular}

is in the spinel or ferrite form. While the $\mathrm{Zn}$ content increases, the $\mathrm{ZnO}$ concentration also increases. However, even with a $28 \% \mathrm{Zn}$ content, the zinc ferrite is relevant ${ }^{16}$. Another author ${ }^{17}$ emphasizes that zinc ferrite percentage in the EAFD is directly proportional to the $\mathrm{Fe} / \mathrm{Zn}$ rate.

\section{Conclusion}

- $\mathrm{ZnFe}_{2} \mathrm{O}_{4}, \mathrm{Fe}_{3} \mathrm{O}_{4}, \mathrm{FeCr}_{2} \mathrm{O}_{4}, \mathrm{Ca}_{0,15} \mathrm{Fe}_{2,85} \mathrm{O}_{4}, \mathrm{SiO}_{2}$ and $\mathrm{ZnO}$ phases are present in the studied EAFD samples;

- $\mathrm{MgFe}_{2} \mathrm{O}_{4}$ phase identified in samples 1 and 2 through the XRD in overlapped peaks, was not observed in the Mössbauer spectra; and

- Concerning $\mathrm{Zn}$ compounds, the greater this element concentration is, the greater $\mathrm{ZnO}$ content and smaller the $\mathrm{ZnFe}_{2} \mathrm{O}_{4}$ content are.

\section{Acknowledgment}

The authors of this paper would like to thank: To CNPq for the financial support, to the technical group of the Mössbauer Spectroscopy Laboratory at the Physics Institute from UFRGS for the support in the experiments and the results interpretation and to GERDAU AEP by handing EAFD sample for the study.

\section{References}

1. Associação Brasileira de Normas Técnicas (ABNT). NBR 10004: resíduos sólidos - Classificação. Rio de Janeiro, 2004.

2. Associação Brasileira de Normas Técnicas (ABNT). NBR 10005: lixiviação de resíduos - procedimentos. Rio de Janeiro.

3. Al-Zaid RZ, Al-Sugair FH, Al-Negheimish AI. Investigation of potential uses of electric-arc furnace dust (EAFD) in concrete. Cement and Concrete Research. 1997; 27(2):267-278.

4. Brehm FA, Graffitti DF, Moraes CAM, Vilela ACF. Desenvolvimento de um método para digestão de pós de aciaria elétrica com vistas à caracterização química do resíduo. In: Congresso em ciência de materiais do Mercosul, Sulmat. Anais do $1^{\circ}$ Sulmat; 2002 Setembro; Joinville, SC; 2002. p. 448-457.

5. Gonçalves JM, Moraes CAM, Brehm, FA, Graffitti DF, Vilela ACF, Electric arc furnace dust reduction using foundry fugitive dust as the main reducing agent. Proceedings in Fourth Japan-Brasil Symposium Dust Processing-energy-environment in Metallurgical Industries; 2002; São Paulo, SP; 2002. p. 263-272. 
6. Brehm FA, Vargas A, Moraes CAM, Masuero A, Dalmolin D, Vilela ACI et al. Characterization and use of eaf dust in construction. Proceedings in Third Japan-Brasil Symposium Dust Processing-energy-environment in Metallurgical Industries; 2001; São Paulo, SP; 2001. p. 173-181.

7. Heck NC, Costa MI, Weber JVV. Caracterização mineralógica do resíduo da lixiviação de poeira da aciaria elétrica. Anais do $55^{\circ}$ Congresso Anual da ABM; 2000 Julho; Rio de Janeiro, RJ; 2000. p. 2667-2675.

8. Long GJ, Cranshaw TE, Longworth G. Mössbauer Effect Data Journal. 1983; 6(1983):42-45.

9. Nyrenda RL, The processing of steelmaking flue dust: a review. Minerals Engineering. 1991; 4(1991):1003-1025.

10. Pelino M, Karamanov A, Pisciella P, Crisucci S, Zonetti D, Vitrification of electric arc furnace dusts. Waste Management. 2002; 22(2002):945-949.

11. Yang Q, Gustafsson B, Studies on Dust Recycling in the Electric Arc Furnace at Uddeholm Tooling AB. Scandinavian Journal of Metallurgy. 2003; 32:147-156.

12. Goya GF, Stewart SJ, Mercader RC. Mössbauer Study of Fe-Zn-O Phases Solid State Communications. 1995; 96(7):485-490.
13. Bluncson CR, Thompson GK, Evans BJ. ${ }^{57} \mathrm{Fe}$ Mössbauer investigations of manganese-containing spinels. Hyperfine Interactions. 1994; 90:53-358.

14. Silva MTX. Aplicação do Efeito Mössbauer à Análise de Amostras de Basalto. M.Sc. [Thesis] UFRGS, Porto Alegre, Rio Grande do Sul, Brazil, 1977.

15. Dubiel SM, Cieslak J, Orewczyk J, Jasienska S. Mössbauer Effect Study of calciomagnetites. Acta Physica Polonica A. 1998; 93(3):547-561.

16. Takano C, Mantovani MC, Cavallante FL, Mourão MB. Electric arc furnace dust characterization and recycling by self reducing pellets. Proceedings First Japan-Brasil Symposium Dust Processing-energyenvironment in Metallurgical Industries; 1999, São Paulo, SP; 1999.

17. Huber JC, Patisson F, Rocabois P, Birat JP, Ablitzer D. Some means to reduce emissions and improve the recovery of electric arc furnace dust by controlling the formation mechanisms. Publicação, reprodução, execução: direitos autorais. Proceedings of the "Rewas'99: Global Symposium on Recycling, Waste Treatment and Clean Technology”. San Sebastián: TMS, INASMET; 1999. p. 1483-1491. 